\title{
Posttraining Ablation of Adult-Generated Olfactory Granule Cells Degrades Odor-Reward Memories
}

\author{
Maithe Arruda-Carvalho, ${ }^{1,2}$ - Katherine G. Akers, ${ }^{1}$ Axel Guskjolen, ${ }^{1,3}$ Masanori Sakaguchi, ${ }^{1}$ Sheena A. Josselyn, ${ }^{1,2,3,4}$ \\ and Paul W. Frankland ${ }^{1,2,3,4}$ \\ ${ }^{1}$ Program in Neurosciences and Mental Health, Hospital for Sick Children, Toronto, Ontario, Canada, M5G 1X8, and ${ }^{2}$ Institute of Medical Science and \\ Departments of ${ }^{3}$ Physiology and ${ }^{4}$ Psychology, University of Toronto, Toronto, Ontario, Canada, M5S 1A8
}

Proliferation of neural progenitor cells in the subventricular zone leads to the continuous generation of new olfactory granule cells (OGCs) throughout life. These cells synaptically integrate into olfactory bulb circuits after $\sim 2$ weeks and transiently exhibit heightened plasticity and responses to novel odors. Although these observations suggest that adult-generated OGCs play important roles in olfactory-related memories, global suppression of olfactory neurogenesis does not typically prevent the formation of odor-reward memories, perhaps because residual OGCs can compensate. Here, we used a transgenic strategy to selectively ablate large numbers of adult-generated OGCs either before or after learning in mice. Consistent with previous studies, pretraining ablation of adult-generated OGCs did not prevent the formation of an odor-reward memory, presumably because existing OGCs can support memory formation in their absence. However, ablation of a similar cohort of adult-generated OGCs after training impaired subsequent memory expression, indicating that if these cells are available at the time of training, they play an essential role in subsequent expression of odor-reward memories. Memory impairment was associated with the loss of adult-generated OGCs that were $>10 \mathrm{~d}$ in age and did not depend on the developmental stage in which they were generated, suggesting that, once sufficiently mature, OGCs generated during juvenility and adulthood play similar roles in the expression of odor-reward memories. Finally, ablation of adult-generated OGCs 1 month after training did not produce amnesia, indicating that adult-generated OGCs play a time-limited role in the expression of odor-reward memories.

Key words: adult neurogenesis; memory; olfactory

\section{Introduction}

Neural progenitor cells in the subventricular zone (SVZ) continuously generate cells that migrate via the rostral migratory stream to populate the olfactory bulb (OB) throughout life (Ming and Song, 2005; Belvindrah et al., 2009; Lepousez et al., 2013). The vast majority of these cells ( $>90 \%$; Winner et al., 2002; Lazarini and Lledo, 2011) differentiate into olfactory granule cells (OGCs) and extend dendrites into the external plexiform layer. After $\sim 2$ weeks, they form reciprocal dendrodendritic contacts with mitral cells, the principal neurons in the OB. Around the same time, input synapses from higher-order regions form, and, soon after, OGCs exhibit heightened plasticity at these input synapses (Carleton et al., 2003; Gao and Strowbridge, 2009; Nissant et al., 2009), are more responsive to novel odors (Magavi et al., 2005;

Received June 1, 2013; revised 0ct. 7, 2014; accepted 0ct. 12, 2014.

Author contributions: M.A.-C., K.G.A., M.S., S.A.J., and P.W.F. designed research; M.A.-C., K.G.A., and A.G. performed research; M.A.-C. and K.G.A. analyzed data; M.A.-C., K.G.A., S.A.J., and P.W.F. wrote the paper.

This work was supported by grants from Brain Canada (P.W.F.). and Canadian Institutes of Health Research Grants MOP86762 (P.W.F.) and MOP74650 (S.A.J.). M.A.-C. and K.G.A. were supported by fellowships from the Ontario Graduate Scholarship program (M.A.-C.), the Hospital for Sick Children (M.A.-C.), and the Canadian Institutes of Health Research (K.G.A.). We thank members of the Frankland/Josselyn laboratories for discussions and technical assistance.

The authors declare no conflicts of interest.

Correspondence should be addressed to Paul W. Frankland, SickKids, Hospital for Sick Children, 686 Bay Street, Toronto, 0N, Canada, M5G 0A4. E-mail: paul.frankland@sickkids.ca.

DOI:10.1523/JNEUROSCI.2336-13.2014

Copyright $\odot 2014$ the authors $\quad 0270-6474 / 14 / 3415793-11 \$ 15.00 / 0$
Belnoue et al., 2011), and are preferentially activated by recall of an odor-reward memory (Sultan et al., 2010). Furthermore, subsequent optical stimulation of this population of cells facilitates the formation of an odor-reward memory (Alonso et al., 2012). These studies suggest that adult-generated OGCs play an important role in the formation of odor memories, but whether they represent an essential component of the odor-related memory trace or, more simply, modulate the efficiency of $\mathrm{OB}$ processing (e.g., by synchronizing mitral cell activity; Mouret et al., 2009; Urban and Arevian, 2009; Cleland, 2010), is less clear.

Examinations of the effect of suppressing olfactory neurogenesis on subsequent odor learning are potentially useful in exploring the role of adult-generated OGCs in odor memory. However, these types of interventions have produced mixed results, with experimental reduction in olfactory neurogenesis frequently not preventing the acquisition of odor memory (Imayoshi et al., 2008; Breton-Provencher et al., 2009; Lazarini et al., 2009; Valley et al., 2009; Sultan et al., 2010), likely because of the potential for existing OGCs to compensate and mask potential deficits. A potentially more powerful approach would be to target adultgenerated OGCs after training, once they have had an opportunity to integrate into an odor-related memory trace (Frankland, 2013). To address this question, we used a transgenic strategy to conditionally express diphtheria toxin receptors (DTRs) in a Cre recombinase-dependent manner (Buch et al., 2005; ArrudaCarvalho et al., 2011). To restrict DT-induced apoptosis to adult- 


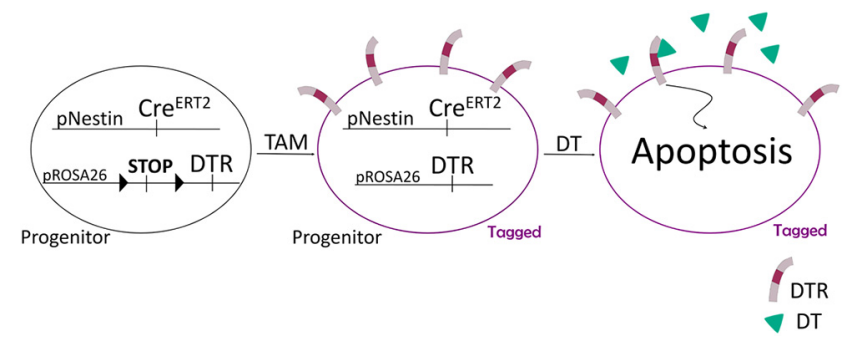

Figure 1. DT-based ablation. Schematic of the tag-and-ablate strategy for ablating mature adult-generated neurons. In adult nestin-Cre ${ }^{\text {ERT2+ }} / \mathrm{iDTR}^{+}$mice $(2 \times \mathrm{Tg})$, TAM administration leads to permanent expression of DTRs in neural progenitor cells and their progeny. Subsequent administration of DT ablates this tagged population of adult-generated neurons only.

generated neurons, we crossed inducible DTR (iDTR) mice with nestin-Cre ${ }^{\text {ERT2 }}$ mice in which a tamoxifen (TAM)-inducible Cre recombinase is expressed under the control of a nestin promoter (Imayoshi et al., 2008). In adult offspring from this cross, TAM administration induces permanent expression of DTRs in neural progenitor cells and their progeny, and subsequent administration of DT ablates only this tagged population of cells (Fig. 1).

By using a line of nestin-Cre ${ }^{\text {ERT2 }}$ mice with highest expression in the hippocampus, we previously used this "tag-and-ablate" approach to examine whether adult-generated dentate granule cells play an essential role in hippocampal memory (ArrudaCarvalho et al., 2011). Here, we use a line of nestin-Cre ${ }^{\text {ERT2 }}$ mice with highest expression in the SVZ to ask whether adultgenerated OGCs play an essential role in odor-reward memory. Our main finding is that posttraining ablation of this population of adult-generated OGCs impairs subsequent expression of an odor-reward memory. Memory loss is associated with loss of OGCs that are $>10 \mathrm{~d}$ in age and does not depend on the developmental stage (juvenility vs adulthood) in which OGCs were generated. Finally, ablation of the same population of cells at remote time points after training is ineffective, suggesting that adult-generated OGCs play a time-limited role the expression of these types of memories.

\section{Materials and Methods}

Mice

nestin-Cre $e^{E R T 2}$ mice. nestin-Cre ${ }^{\text {ERT2+ }}$ mice express a TAM-inducible form of Cre recombinase under the control of a nestin promoter, as described previously (Imayoshi et al., 2008). We compared recombination in two lines of nestin-Cre ${ }^{\text {ERT2 }}$ mice corresponding to lines 4 and 5-1 in the study by Imayoshi et al. (2008), and we chose to use line 5-1 because the recombination rate was significantly higher in the SVZ.

iDTR mice. iDTR mice have been described previously (Buch et al., 2005; Gropp et al., 2005). In iDTR-expressing (iDTR ${ }^{+}$) mice, the gene encoding DTR [simian Hbegf (heparin-binding epidermal growth factor-like growth factor)] is under the control of the ubiquitous Rosa26 locus promoter, but expression of the DTR transgene is dependent on the Cre recombinase-mediated removal of a transcriptional STOP cassette. It is important to note that neither high doses of DT in wild-type mice (Saito et al., 2001) nor expression of DTR alone (without DT) (Buch et al., 2005) produces behavioral abnormalities or cell death.

Rosa-LacZ mice. The Rosa-LacZ reporter mice have been described previously (Zambrowicz et al., 1997). Similar to iDTR mice, the gene encoding LacZ is under the control of the ubiquitous Rosa26 locus promoter, and expression of the LacZ transgene is dependent on the Cre recombinase-mediated removal of a transcriptional STOP cassette. We crossed this reporter line with nestin-Cre ${ }^{\text {ERT2 }}$ mice to initially characterize TAM-induced recombination because, unlike LacZ that is expressed in the nucleus, DTRs are expressed as membrane proteins and are therefore difficult to quantify precisely. Importantly, we observed similar patterns of LacZ and DTR expression after TAM treatment when crossed with nestin-Cre ${ }^{\text {ERT2 }}$ mice.

All lines were maintained on a C57BL/6 background (Taconic Farms). Genotypes were determined by PCR analysis of tail DNA samples as described previously (Zambrowicz et al., 1997; Buch et al., 2005; Imayoshi et al., 2008). nestin-Cre ${ }^{\mathrm{ERT} 2+}$ mice were bred with $\mathrm{iDTR}^{+/-}$or $\mathrm{iDTR}^{+/+}$mice, resulting in nestin-Cre ${ }^{\mathrm{ERT} 2+} / \mathrm{iDTR}^{+}$, nestin-Cre ${ }^{\mathrm{ERT} 2+} /$ $\mathrm{iDTR}^{-}$, nestin-Cre ${ }^{\mathrm{ERT}^{2}-} / \mathrm{iDTR}^{+}$, or nestin-Cre ${ }^{\mathrm{ERT} 2-} / \mathrm{iDTR}^{-}$offspring. An equivalent breeding strategy was used for the LacZ reporter line. Except in the case of wild-type mice, all of transgenes were kept as heterozygous in the chromosome of each transgenic mouse to avoid possible complications by overexpressing Cre recombinase (Forni et al., 2006) or loss of the Rosa allele (Zambrowicz et al., 1997). In most ablation experiments, we compared double transgenic mice $\left(2 \times \mathrm{Tg}\right.$, nestin-Cre $\left.{ }^{\mathrm{ERT} 2+} / \mathrm{iDTR}^{+}\right)$ to control, single transgenic littermate mice (CTR, nestin-Cre ${ }^{\text {ERT2+ }}$ / $\mathrm{iDTR}^{-}$or nestin-Cre $\left.\mathrm{ERT2}^{\mathrm{ER}} / \mathrm{iDTR}^{+}\right)$. In one experiment, nestin$\mathrm{Cre}^{\mathrm{ERT} 2+}$ mice from a Rosa-LacZ cross were also used as controls. Both CTR and $2 \times$ Tg mice were treated with TAM and subsequently DT (see below).

All mice were bred in our colony at the Hospital for Sick Children and maintained on a $12 \mathrm{~h}$ light/dark cycle with access to food and water ad libitum. Before all behavioral experiments, mice were handled for 2 $\mathrm{min} / \mathrm{d}$ for $5 \mathrm{~d}$. Male and female offspring were used in all experiments. All experiments were performed during the light cycle and approved by the Hospital for Sick Children Animal Care and Use Committee.

\section{Drugs}

TAM treatment. TAM (Sigma) was dissolved in minimal ethanol (10\%) and suspended in sunflower seed oil (30 mg/ml; Lagace et al., 2007). Mice received daily injections ( $180 \mathrm{mg} / \mathrm{kg}$, i.p.) for $5 \mathrm{~d}$. TAM injections started when mice were 8 (adult) or 4-5 (juvenile) weeks old.

DT treatment. Preparation and delivery of DT has been described previously (Han et al., 2009). DT (Sigma) was dissolved in PBS (500 ng/ $\mu \mathrm{l}$ ) and readily crosses the blood-brain barrier (Wrobel et al., 1990). Mice received daily injections of DT ( $16 \mu \mathrm{g} / \mathrm{kg}$, i.p) for $5 \mathrm{~d}$.

\section{Immunohistochemistry}

Mice were perfused transcardially with PBS $(0.1 \mathrm{M})$ and $4 \%$ paraformaldehyde (PFA). Brains were removed, fixed overnight in PFA, and transferred to $0.1 \mathrm{M}$ PBS. Coronal sections $(40 \mu \mathrm{m})$ were cut using a vibratome (Leica VT1200S). The following primary antibodies were used: goat polyclonal anti-doublecortin (DCX; 1:4500; Santa Cruz Biotechnology), rabbit polyclonal anti-ER $\alpha$ (1:1000; Santa Cruz Biotechnology), mouse monoclonal anti-NeuN (1:1000; Millipore), rabbit polyclonal anti-LacZ (1:6000; Invitrogen), mouse monoclonal anti-nestin (1:150; BD Pharmingen), rabbit polyclonal anti-Ki67 (1:200; Abcam), rabbit polyclonal anti-cleaved caspase-3 (Asp175; 1:1000; Cell Signaling Technology), and rabbit polyclonal anti-Egr-1 (588; zif268; Santa Cruz Biotechnology). All sections were treated with $1 \%$ hydrogen peroxidase. Sections were then incubated overnight with the primary antibody and then for $60 \mathrm{~min}$ at $20^{\circ} \mathrm{C}$ with HRP-conjugated or biotinylated secondary antibodies (1:750; Jackson ImmunoResearch). Signals were amplified and visualized using Vectastain Elite ABC kit (Vector Laboratories), tyramide signal amplification, and/or Alexa Fluor-conjugated streptavidin (Invitrogen). Sections were mounted on slides with Permafluor anti-fade medium.

\section{Imaging and quantification}

All images were acquired using epifluorescent (either a Nikon Eclipse 80i or an Olympus BX61) or confocal (LSM 710 Zeiss) microscopes. To calculate cell number, cell density, or proportion of double-positive cells, we used $1 / 5$ systematic section sampling fractions covering the entire anterior-posterior extent of the SVZ or OB. To calculate the proportion of double-labeled cells, confocal $1 \mu \mathrm{m} Z$ Z-stack images were obtained using ZEN software (Zeiss) with a minimal interval of $15 \mu \mathrm{m}$ to prevent duplicate counts of the same cell. We quantified $\mathrm{Ki}^{+}{ }^{+}$cells throughout the anterior-posterior extent of the SVZ using a $10 \times$ objective on the Nikon epifluorescence microscope. We estimated the total number of $\mathrm{LacZ}^{+}$ cells after TAM treatment using the optical fractionator method on the Olympus epifluorescence microscope using a $60 \times, 1.45$ numerical aper- 
ture objective and a motorized $x-y-z$ stage attached to a computer with Stereoinvestigator 9.1 software (MBF Bioscience; Chen et al., 2004). A random systematic sampling was used for these stereological analyses (section interval of $1 / 5$, grid size of $300 \times 300 \mu \mathrm{m}$, two-dimensional counting frame of $60 \times 60 \mu \mathrm{m}$ using fractionators of $30 \mu \mathrm{m}$ thickness). Tissue thickness measured in each counting frame was used to estimate the total number of $\mathrm{LacZ}^{+}$cells in the entire OB. Conditions were optimized to obtain a Gundersen coefficient of error below 0.05 (Gundersen et al., 1999).We quantified cleaved caspase- $3^{+}$cells throughout the entire anterior-posterior extent of the $\mathrm{OB}$ using the Nikon microscope.

\section{General behavioral apparatus and procedures}

Odor-reward memory task. The apparatus and training schedule have been described previously (Imayoshi et al., 2008; Akers et al., 2011). Mice were food restricted to maintain $\sim 90 \%$ of normal body weight and trained for $4 \mathrm{~d}$ in the odor-reward task. On each day of training, mice were given one reinforced and one non-reinforced trial. In all trials, the odorant solution [the enantiomers $(+)$ or $(-)$ carvone, diluted in mineral oil at a concentration of $10^{-2}$ ] was pipetted onto filter paper. The filter paper was placed inside a Petri dish $(60 \times 15 \mathrm{~mm})$ with a perforated cover to allow for odor flow. The scented Petri dish was covered in bedding and placed at one end of a mouse cage $(32 \times 18 \times 14 \mathrm{~cm})$. During the reinforced trial, six sugar pellets $(10 \mathrm{mg}$ each) were placed beneath the bedding on top of the scented Petri dish. During the nonreinforced trial, no sugar was buried below the bedding. The reinforced odor and order of odor exposure were counterbalanced across mice. Training trials were $5 \mathrm{~min}$ in duration.

For the probe tests, mice were placed in a cage with both odors present but in the absence of sugar for $10 \mathrm{~min}$. Odor-reward memory was measured as time spent digging over the correct odor. All probe tests were video recorded and manually coded. A preference index was calculated as $\left[\left(\right.\right.$ digging $_{\text {reinforced odor }}-$ digging $\left._{\text {non-reinforced odor }}\right) /\left(\right.$ digging $_{\text {reinforced odor }}$ + digging $_{\text {non-reinforced odor }}$ )]. Performance in this task has been shown to be hippocampus independent (Akers et al., 2011).

\section{Specific experimental protocols}

Characterization of TAM-induced recombination. Four- to five- and eight-week-old nestin-Cre ${ }^{\text {ERT2+ }} /$ Rosa-LacZ ${ }^{+}$mice $(n=5-7)$ were treated with TAM. Three weeks after the completion of TAM treatment, the number, distribution, and cellular phenotype of recombined LacZ ${ }^{+}$ cells were quantified using immunohistochemical methods.

Characterization of TAM-induced recombination and ablation in $2 \times \mathrm{Tg}$ mice. Four- to 5 -week-old $2 \times \mathrm{Tg}$ mice were treated with TAM. Three weeks after the completion of TAM treatment, mice received daily injections of PBS $(n=4)$ or DT $(n=5)$ for $5 \mathrm{~d}$. Twenty-four h after the final DT injection, mice were perfused, and cleaved caspase- 3 expression was quantified using immunohistochemical methods.

Open field. CTR ( $4-5$ weeks old, $n=15 ; 8$ weeks old, $n=10$ ) and $2 \times \operatorname{Tg}(4-5$ weeks old, $n=10 ; 8$ weeks old, $n=7)$ mice were treated with TAM. Three weeks later, mice received daily injections of DT for $5 \mathrm{~d}$. Twenty-four hours after the final DT injection, mice were placed in the center of a square-shaped open-field arena $(45 \times 45 \times 20 \mathrm{~cm})$ and allowed to explore for $10 \mathrm{~min}$. The open-field apparatus was constructed of Plexiglas and was dimly lit from above. Mouse location was tracked by a camera located above the open field, and total distance traveled as well as time spent in three different zones (outer, middle, inner) was recorded (Limelight2; Actimetrics). Total distance traveled was used as a measure of spontaneous motor activity, and distribution of activity in different regions of the arena was used as a measure of anxiety-related behavior (Archer, 1973).

Odor-reward memory task: posttraining ablation (adult mice). Eightweek-old CTR $(n=16)$ and $2 \times \operatorname{Tg}(n=26)$ mice were treated with TAM. Three weeks later, mice were trained in the odor-reward memory task for $4 \mathrm{~d}$. Twenty-four hours after the completion of training, odor preference was assessed (pre-DT probe). Starting the following day, mice received daily DT injections for $5 \mathrm{~d}$. Twenty-four hours after the final injection, odor preference was reassessed (post-DT probe). In a second experiment, CTR $(n=8)$ and $2 \times \operatorname{Tg}(n=10)$ mice were treated identically but were trained $10 \mathrm{~d}$ (not 3 weeks) after TAM treatment.
Odor-reward memory task: posttraining ablation (juvenile mice). Fourto five-week-old CTR $(n=18)$ and $2 \times \operatorname{Tg}(n=19)$ mice were treated with TAM. Three weeks later, mice were trained in the odor-reward memory task for $4 \mathrm{~d}$. Twenty-four hours after the completion of training, odor preference was assessed (pre-DT probe). Starting the following day, mice received daily DT injections for $5 \mathrm{~d}$. Twenty-four hours after the final injection, odor preference was reassessed (post-DT probe).

Odor-reward memory task: pretraining ablation (adult mice). Eightweek-old CTR $(n=10)$ and $2 \times \operatorname{Tg}(n=11)$ mice were treated with TAM. Three weeks later, mice were trained in the odor-reward memory task for $4 \mathrm{~d}$. Twenty-four hours after the completion of training, odor preference was assessed in a probe test. Mice received daily injections of DT for $5 \mathrm{~d}$ immediately preceding training.

Odor-reward memory task: pretraining ablation (juvenile mice). Fourto five-week-old CTR $(n=15)$ and $2 \times \operatorname{Tg}(n=15)$ mice were treated with TAM. Three weeks later, mice were trained in the odor-reward memory task for $4 \mathrm{~d}$. Twenty-four hours or $28 \mathrm{~d}$ after the completion of training, odor preference was assessed in a probe test. Mice received daily injections of DT for $5 \mathrm{~d}$ immediately preceding training.

Odor-reward memory task: remote posttraining ablation. Eight-weekold CTR $(n=16)$ and $2 \times \operatorname{Tg}(n=8)$ mice were treated with TAM. Three weeks later, mice were trained in the odor-reward memory task for $4 \mathrm{~d}$. Twenty-four hours after the completion of training, odor preference was assessed (pre-DT probe). Starting $23 \mathrm{~d}$ later, mice received daily injections of DT for $5 \mathrm{~d}$. Twenty-four hours later, odor preference was reassessed (post-DT probe).

\section{Data analysis}

Cleaved caspase-3 data were analyzed using a planned, one-tailed independent samples $t$ test, and open-field data were analyzed using ANOVA. Odor-reward task data (i.e., dig durations and preference indices) were analyzed using ANOVAs, followed by Bonferroni's post hoc tests or planned, two-tailed paired and independent samples $t$ tests. We initially included sex as a factor in our analyses but found no significant sex effects; therefore, this factor was dropped from analysis.

\section{Results}

\section{Characterization of tag-and-ablate mice}

We first characterized TAM-induced recombination ("tagging") in nestin-Cre ${ }^{\text {ERT2 }}$ mice by crossing them with Rosa-LacZ reporter mice. In these reporter mice, Cre-mediated excision of a STOP cassette induces LacZ expression under the control of the Rosa26 promoter (the same promoter as in the iDTR mice). Consistent with previous results (Arruda-Carvalho et al., 2011), Cre ${ }^{\text {ERT2 }}$ protein expression was limited to adult neurogenic regions (including the SVZ) in both 4- and 8-week-old mice (Fig. $2 a, b)$. Within the SVZ, Cre ${ }^{\text {ERT2 }}$ protein was exclusively colocalized with the neural progenitor marker nestin (Fig. 2c,d; Table 1) but not the neuroblast (Type A cell) marker DCX (Fig. 2e,f; Table 1; Imayoshi et al., 2008).

As expected, in 8-week-old nestin-Cre ${ }^{\text {ERT2+ }} /$ Rosa-LacZ ${ }^{+}$reporter mice, TAM-induced recombination was efficient, with $58.5 \pm 4.8 \%$ (mean \pm SEM) of $\mathrm{Ki}^{+}{ }^{+}$cells coexpressing LacZ (Fig. $2 g$ ). Three weeks after TAM treatment, $\mathrm{LacZ}^{+}$cells were found throughout the granule cell layer of the OB (Fig. $2 h$ ), suggesting that large numbers of recombined cells differentiated into OGCs. Using stereological methods, we estimated that there were $141,337 \pm 4106 \mathrm{LacZ}^{+}$cells, which corresponds to $\sim 10 \%$ of the entire population of OGCs (Imayoshi et al., 2008). There were fewer $\mathrm{LacZ}^{+}$cells located in the glomerular layer, indicating that a much smaller fraction of cells differentiated into periglomerular cells, as expected. TAM-induced recombination was similarly efficient in 4-week-old mice, with $146,452 \pm 16,033 \mathrm{LacZ}^{+}$cells in the granule cell layer of the OB after a 3 week delay (Fig. $2 i$ ). These numbers of $\mathrm{LacZ}^{+}$cells in the $\mathrm{OB}$ using the current Cre-driver line (corresponding to line 5-1 in the study by Imayoshi et al., 

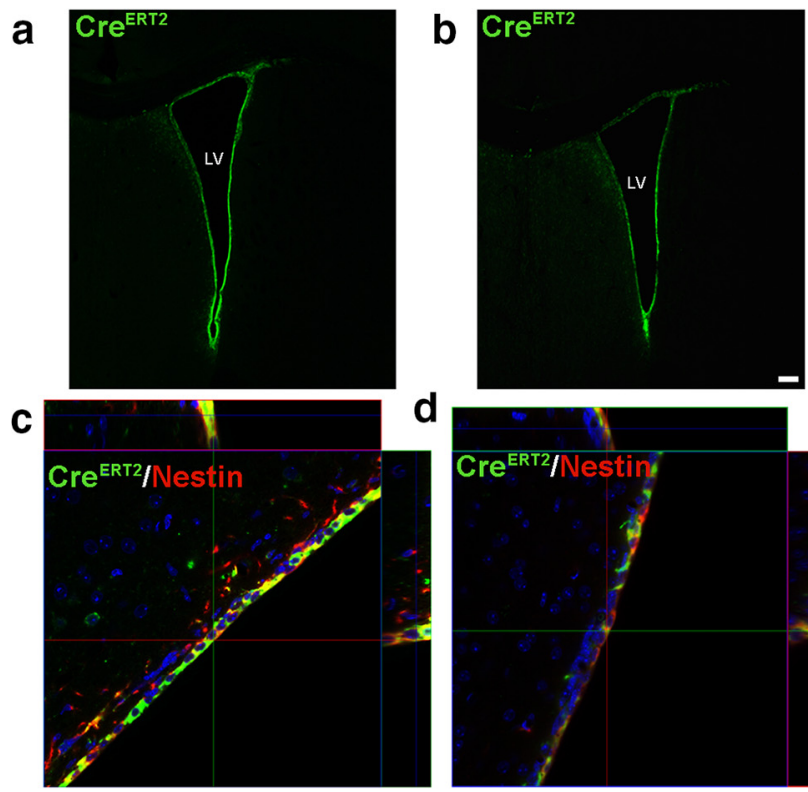

d

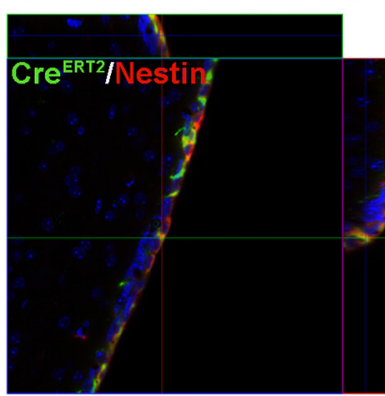

e
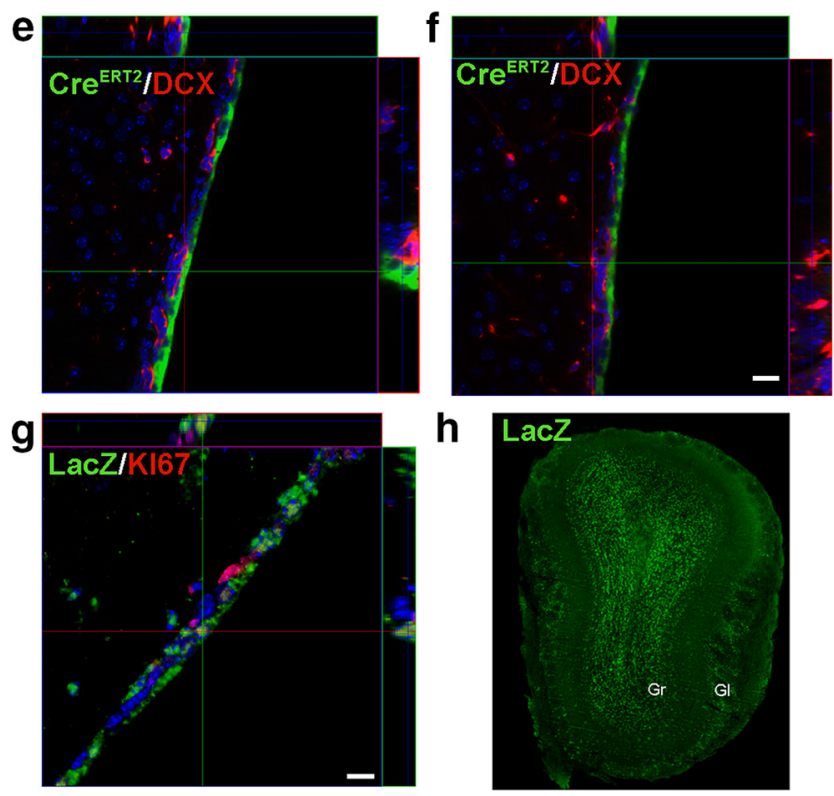

i

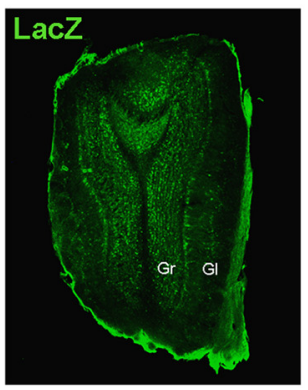

j

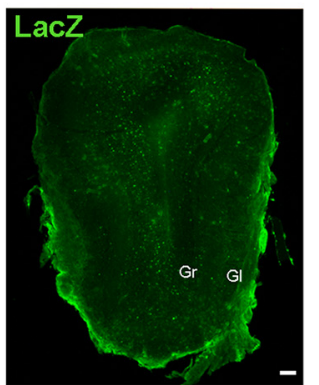

Figure 2. Cre ${ }^{\text {ERT2 }}$ expression is restricted to progenitor cells and limited to adult neurogenic regions. In nestin-Cre ${ }^{\text {ERT2+ }}$ mice, $\mathrm{Cre}^{\text {ERT2 }}$ protein expression was limited to adult neurogenic regions, including the SVZ of the lateral ventricle (LV) in 4-week-old (a) and 8-week-old (b) mice. Scale bar, $100 \mu \mathrm{m}$. In these mice, (re ${ }^{\text {ERT2 }}$ protein expression (green) was found in nestin ${ }^{+}(\boldsymbol{c}$, d) butnot DCX ${ }^{+}(\boldsymbol{e}, \boldsymbol{f})$ cells (red) in 4-week-old and 8-week-old mice, respectively. Scale bar, $10 \mu \mathrm{m}$. $\boldsymbol{g}$, TAM-induced recombination was efficient, with $\sim 59 \%$ of $\mathrm{LaCZ}^{+}$cells in the SVZ also expressing the proliferation marker Ki67. Scale bar, $10 \mu \mathrm{m}$. Three weeks after TAM treatment, LacZ ${ }^{+}$cells were found throughout the granule cell layer ( $\mathrm{Gr}$ ) of the OB in 4-week-old $(\boldsymbol{h})$ and 8-week-old (i) mice. Fewer LaCZ ${ }^{+}$cells were found in the glomerular cell layer (Gl), likely corresponding to periglomerular

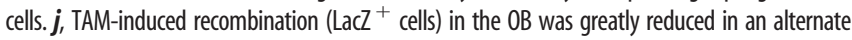
Cre-driver line (line 4 from the study by Imayoshi et al., 2008). Scale bar, $100 \mu \mathrm{m}$.
Table 1. CRE ${ }^{\text {ERT2 }}$ expression pattern

\begin{tabular}{llllll}
\hline \multirow{2}{*}{ Cell maturity marker } & 4 weeks & & & 8 weeks & \\
\cline { 2 - 3 } \cline { 5 - 6 } $\begin{array}{l}\text { Percentage } \pm \text { SEM of CRE ERT2+ } \\
\text { cells expressing marker }\end{array}$ & $95.9 \pm 1.2$ & $2.6 \pm 0.3$ & & $98.1 \pm 0.7$ & $1.8 \pm 0.4$ \\
$\begin{array}{l}\text { Cells analyzed }\end{array}$ & 537 & 536 & & 649 & 706 \\
\hline
\end{tabular}

2008) were much higher than those observed in our previous study using an alternate nestin-Cre ${ }^{\mathrm{ERT} 2+}$ line (corresponding to line 4 in the study by Imayoshi et al., 2008; Fig. $2 j$ ).

To evaluate the phenotype of these cells, we next stained for proteins expressed at different stages of cell differentiation. In 8-week-old mice, $50 \%$ of tagged $\left(\mathrm{LacZ}^{+}\right)$cells were $\mathrm{DCX}^{+}$, whereas $67 \%$ were $\mathrm{NeuN}^{+}$(Fig. $3 a, b$; Table 2). In 4-week-old mice, $33 \%$ of tagged $\left(\mathrm{LacZ}^{+}\right)$cells were $\mathrm{DCX}^{+}$, whereas $63 \%$ were $\mathrm{NeuN}^{+}$(Fig. 3c,d;Table 2). Because DCX is expressed in neuroblasts and immature neurons and $\mathrm{NeuN}$ is expressed only in neurons, this suggests that the population of tagged neurons includes large numbers of late-stage $\mathrm{DCX}^{+}$cells, corresponding to a time point when OGCs display enhanced input plasticity (Nissant et al., 2009) and responses to novel odors (Magavi et al., 2005). Accordingly, at this time point, LacZ ${ }^{+}$ cells expressed activity-dependent genes such as zif268 after training (Fig. 3e).

To ablate these tagged neurons, we crossed nestin-Cre ${ }^{\text {ERT2 }}$ mice with iDTR mice in which Cre-mediated excision of a STOP cassette renders cells sensitive to DT (Buch et al., 2005). In previous studies, we and others showed that administration of DT leads to apoptosis of DTR-tagged cells (Buch et al., 2005; Han et al., 2009; Arruda-Carvalho et al., 2011; Vukovic et al., 2013; Whiddon and Palmiter, 2013). Three weeks after TAM treatment, we confirmed that systemic injection of DT (but not PBS) led to an increase in cleaved caspase- $3^{+}$cells in $2 \times \mathrm{Tg}$ mice $\left(t_{(7)}=\right.$ $2.24, p<0.05$; Fig. $3 f, g)$. This increase was limited to the granule cell layer of the OB, matching the location of DTR-expressing cells. As we have observed previously, there were no overt changes in behavior after DT-induced ablation. In the open field, $2 \times \mathrm{Tg}$ and littermate CTR mice (either nestin-Cre ${ }^{\mathrm{ERT} 2+}$ or $\mathrm{iDTR}^{+}$but not both) traveled an equivalent distance (4 weeks old: $2 \times \mathrm{Tg}, 5.0 \pm 0.7 \mathrm{~m}$; CTR, $4.1 \pm 0.1 \mathrm{~m}, t_{(22)}=1.53, p=0.14$; 8 weeks old: $2 \times \mathrm{Tg}, 4.9 \pm 1.0 \mathrm{~m}$; CTR, $6.8 \pm 0.3 \mathrm{~m}, t_{(15)}=1.97$, $p=0.068)$ and spent equivalent time in different regions of the arena ( 4 weeks old: genotype $\times$ zone ANOVA, zone main effect, $F_{(2,46)}=374.3, p<0.0001$; genotype $\times$ zone interaction, $F_{(2,46)}=$ $1.54, p=0.23$; 8 weeks old: genotype $\times$ zone ANOVA, zone main effect, $F_{(2,30)}=1248.9, p<0.0001$; genotype $\times$ zone interaction, $F_{(2,30)}=0.01, p=0.99$; Fig. 3h,i). In all subsequent behavioral experiments, CTR and $2 \times \mathrm{Tg}$ mice were treated with TAM and subsequently treated with DT either before or after training. Importantly, this design ensures that group effects cannot be attributed to nonspecific effects of TAM or DT.

\section{Posttraining ablation of adult-generated OGCs impairs expression of an odor-reward memory}

Adult-generated OGCs synaptically integrate $\sim 2$ weeks after birth (Carleton et al., 2003). From 2-4 weeks of age, adultgenerated OGCs exhibit enhanced responsivity to novel odors (Magavi et al., 2005) and enhanced plasticity at input synapses (Nissant et al., 2009) compared with preexisting OGCs. Therefore, to test whether this population of adult-generated OGCs form an essential component of an odor-related memory, 8 -week-old (adult) CTR and $2 \times \mathrm{Tg}$ mice were treated with TAM 

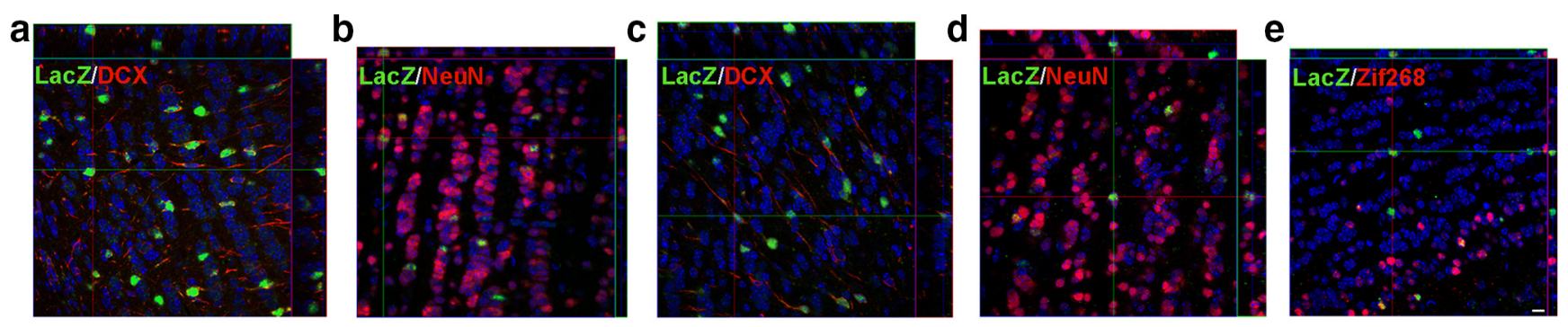

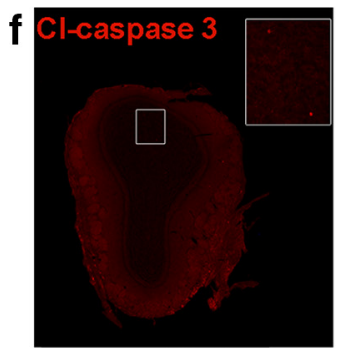

2xTg/PBS

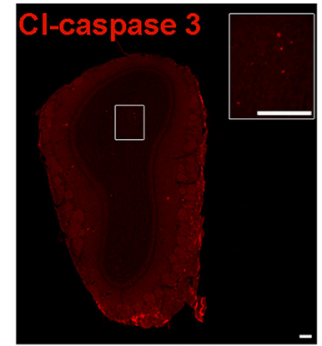

2xTg/DT

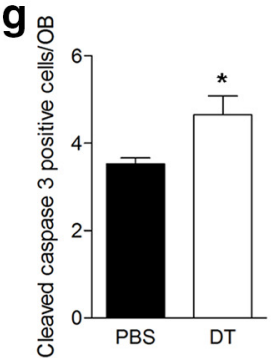

h

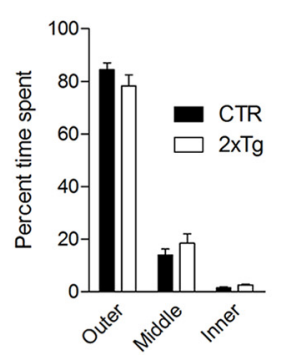

i

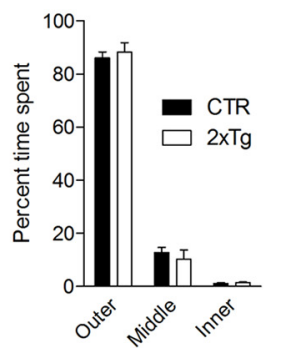

Figure 3. Tagging new neurons. Three weeks after the completion of TAM treatment in 4-week-old $(\boldsymbol{a}, \boldsymbol{b})$ and 8-week-old (c, $\boldsymbol{d})$ adult mice, most LacZ ${ }^{+}$cells (green) costained for neuronal markers (NeuN, DCX; red). $\boldsymbol{e}, \mathrm{LacZ}^{+}$cells additionally expressed activity-dependent gene zif268 (red) after behavioral testing. Scale bar, $10 \mu \mathrm{m}$. $\boldsymbol{f}, \boldsymbol{g}$, In $2 \times \mathrm{Tg}$ mice, DT treatment increased the number of cleaved caspase- $3^{+}$(Cl-caspase 3$)$ cells in the granule cell layer. Scale bar, $100 \mu \mathrm{m}$. Insets show higher magnification of selected areas. Scale bar, $50 \mu \mathrm{m}$. After DT-induced ablation, time spent in the outer, middle, and inner regions of the open field were unaltered in 4-week-old (h) and 8-week-old (i) mice. ${ }^{*} p<0.05$.

\section{Table 2. Phenotype of tagged cells}

\begin{tabular}{llllll}
\hline & 4 weeks & & 8 weeks \\
\cline { 2 - 3 } \cline { 5 - 6 } Cell maturity marker & DCX & NeuN & & DCX & NeuN \\
\hline $\begin{array}{l}\text { Percentage } \pm \text { SEM of LacZ } \\
\begin{array}{c}\text { cells expressing marker } \\
\text { Cells analyzed }\end{array}\end{array}$ & $50.2 \pm 3.2$ & $67.2 \pm 1.6$ & & $32.6 \pm 2.7$ & $63.2 \pm 2.3$ \\
\hline
\end{tabular}

and trained in an associative odor-reward task 3 weeks later (Fig. 4a). This post-TAM delay corresponds to a time point when large numbers of adult-generated cells have reached the OB (Fig. $2 h$ ) and express mature neuronal markers, such as NeuN (Fig. 3b; Table 1). In the odor-reward task (Schellinck et al., 2001), foodrestricted mice learn to discriminate between two similar odors [the enantiomers $(+)$ and $(-)$ carvone], one of which is reinforced with sugar pellets. Twenty-four hours after the completion of training, memory for the odor-reward association was assessed in a probe trial in which both odors were present in the absence of sugar. This form of odor-reward memory does not depend on the hippocampus (Akers et al., 2011). In the (pre-DT) probe test, both CTR and $2 \times \mathrm{Tg}$ mice spent more time digging near the previously reinforced odor $\left(\mathrm{CTR}, t_{(15)}=8.02, p<0.001\right.$; $2 \times \mathrm{Tg}, t_{(25)}=7.45, p<0.0001$; Fig. $\left.4 b, c\right)$, indicating that expression of DTRs in OGCs did not affect motivation or motor skills necessary to acquire the odor-reward memory.

CTR and $2 \times$ Tg mice were subsequently treated with DT, and odor memory was reassessed $6 \mathrm{~d}$ later. In this (post-DT) probe test, CTR mice continued to spend more time digging near the previously reinforced odor $\left(t_{(15)}=3.79, p<0.005\right)$, indicating that the odor-reward memory was stable and did not undergo extinction through retesting (Fig. $4 b$ ). In contrast, $2 \times$ Tg mice spent equivalent time digging over both odors $\left(t_{(25)}=0.97, p=\right.$ 0.34 ; Fig. $4 c$ ), indicating that posttraining ablation of adultgenerated OGCs led to memory loss. Comparisons of pre-DT versus post-DT preference indices support this conclusion. An ANOVA with genotype (CTR, $2 \times \mathrm{Tg}$ ) as a between-subjects variable and test time (pre-DT, post-DT) as a within-subjects vari- able revealed main effects of genotype $\left(F_{(1,40)}=7.05, p<0.005\right)$, test time $\left(F_{(1,40)}=10.09, p<0.005\right)$, and a genotype $\times$ test time interaction $\left(F_{(1,40)}=4.55, p<0.05\right)$. Whereas preference for the previously reinforced odor was similar before and after DT treatment in CTR mice $(p>0.05)$, it was significantly reduced after DT treatment in $2 \times \operatorname{Tg}$ mice $(p<0.05)$. Furthermore, preference for the reinforced odor during the post-DT probe test was significantly reduced in $2 \times \mathrm{Tg}$ compared with CTR mice $(p<$ 0.05; Fig. $4 d$ ).

Although these results suggest that adult-generated cells form an essential component of the odor-reward memory trace, the tagged population of cells is heterogeneous in terms of location and maturity. Therefore, memory loss might be related to a loss of relatively mature adult-generated OGCs in the OB or, alternatively, a loss of less mature cell types located in the $\mathrm{OB}$ or the rostral migratory stream. To address this limitation, we next treated adult CTR and $2 \times \mathrm{Tg}$ mice with TAM and trained them in the odor-reward task $10 \mathrm{~d}$, rather than 3 weeks, later (Fig. $4 e$ ). In this case, posttraining ablation did not affect the expression of the odor-reward association. Both CTR and $2 \times$ Tg mice expressed a preference for the reinforced odor in probe tests before and after DT treatment (pre-DT ${ }_{\mathrm{CTR}}, t_{(7)}=3.09, p<0.05$; post-DT $_{\mathrm{CTR}}$, $t_{(7)}=4.99, p<0.005$; pre-DT $2 \times \mathrm{Tg}, t_{(9)}=4.31, p<0.005$; post$\mathrm{DT}_{2 \times \mathrm{Tg}}, t_{(9)}=3.32, p<0.01$; Fig. $\left.4 f, g\right)$, and the magnitude of this preference was similar at both time points for both CTR and $2 \times$ Tg mice (genotype $\times$ test time ANOVA, no main effects or interactions, all $F$ values $<1$; Fig. $4 h$ ). These findings suggest that the loss of adult-generated cells $>10 \mathrm{~d}$ in age is responsible for memory impairment after posttraining DT treatment. This population primarily corresponds to OGCs that have reached the OB and formed input/output connections with mitral cells within the $\mathrm{OB}$ and higher association areas, including the piriform cortex, anterior olfactory nucleus, and cortical amygdaloid nucleus (Lepousez et al., 2013). The results also suggest that secondary effects of the death of large numbers of cells do not generally disrupt $\mathrm{OB}$ function. 


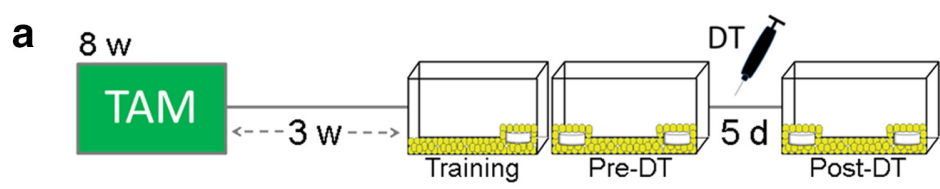

b

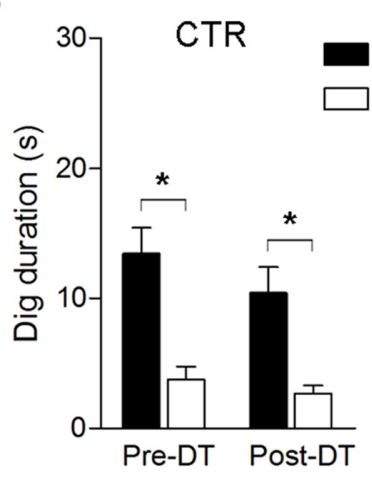

c

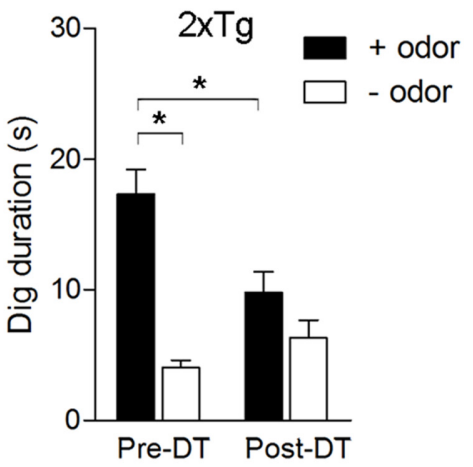

d

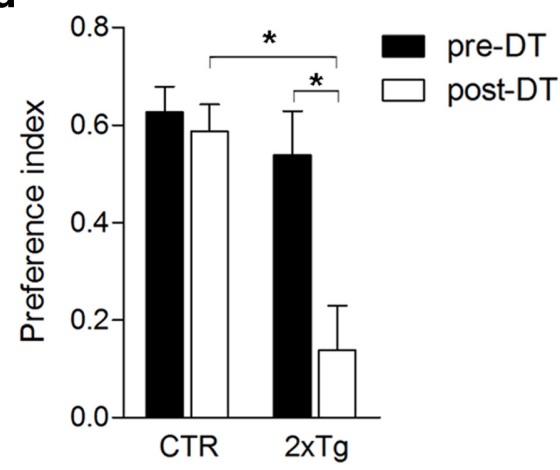

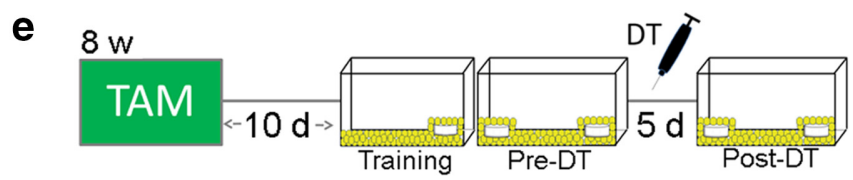

f

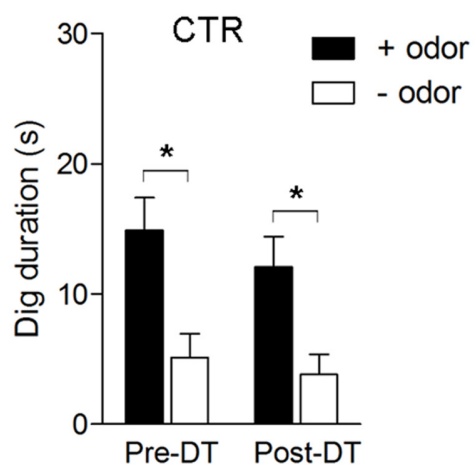

g

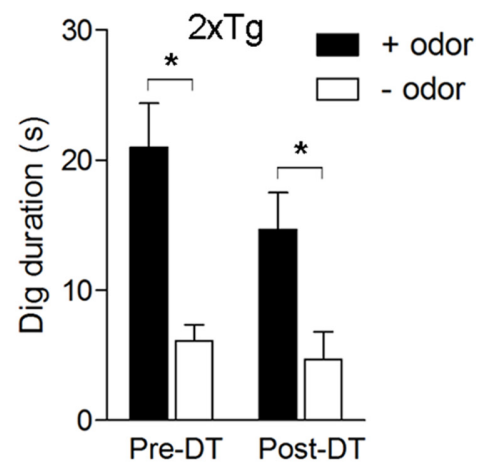

h

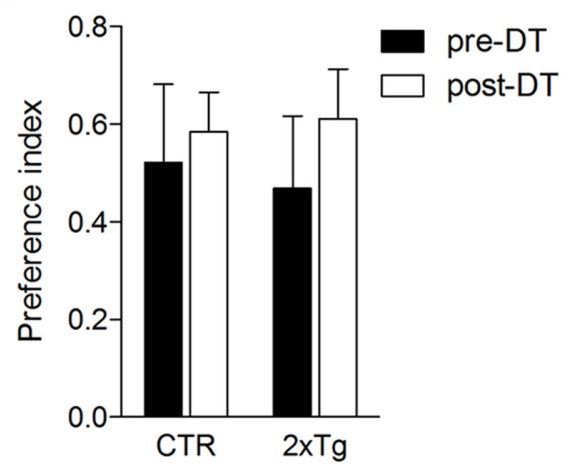

Figure 4. Posttraining ablation of adult-generated OGCs impairs expression of odor-reward memory. $\boldsymbol{a}$, Adult (8-week-old) mice were treated with TAM and trained in the odor-reward task 3 weeks later. 0dor-reward memory was evaluated $1 \mathrm{~d}$ after training (pre-DT probe) and again after DT treatment (post-DT probe). $\boldsymbol{b}$, CTR mice spent more time digging over the previously reinforced odor in the probe tests before and after DT treatment. c, Although $2 \times \mathrm{Tg}$ mice spent more time digging over the previously reinforced odor in the pre-DT probe test, they spent equivalent time digging over the reinforced versus non-reinforced odors in the post-DT test. $\boldsymbol{d}$, Preference indices for CTR and $2 \times$ Tg mice in the pre-DT and post-DT tests. $\boldsymbol{e}$, Adult mice were treated with TAM and trained in the odor-reward task $10 \mathrm{~d}$ later. 0dor-reward memory was evaluated $1 \mathrm{~d}$ after training (pre-DT probe) and again after DT treatment (post-DT probe). Both (TR (f) and $2 \times \mathrm{Tg}(\boldsymbol{g})$ mice spent more time digging over the previously reinforced odor in the probe tests before and after DT treatment. $\boldsymbol{h}$, Preference indices for CTR and $2 \times \operatorname{Tg}$ mice in the pre-DT and post-DT tests. ${ }^{*} p<0.05$.

Pretraining ablation of adult-generated OGCs does not prevent formation of an odor-reward memory

We next tested whether ablation of a similar population of adultgenerated OGCs immediately before training would impair acquisition of a new odor-reward memory. As in the first experiment, adult CTR and $2 \times \mathrm{Tg}$ mice were treated with TAM, trained 3 weeks later, and then tested. In this case, however, DT was administered during the week before training rather than the week after training (Fig. 5a). This experimental design ensures that DT targets an equivalent population of cells (in terms of number and maturity).

In a probe test $1 \mathrm{~d}$ after the completion of training, both CTR $\left(t_{(9)}=3.99, p<0.005\right)$ and $2 \times \mathrm{Tg}\left(t_{(10)}=3.66, p<0.005\right)$ mice expressed a preference for the reinforced odor, indicating that pretraining ablation of adult-generated OGCs does not prevent the formation of a new odor-reward memory (Fig. 5b,c). Using different strategies to suppress olfactory neurogenesis before training in adult rodents, previous studies have similarly found that the ability to form an olfactory associative memory is unaffected (Imayoshi et al., 2008; Breton-Provencher et al., 2009; Lazarini et al., 2009; Sultan et al., 2010). In some instances, however, deficits in the persistence of odor-reward memories have been detected in rodents with suppressed olfactory neurogenesis (Breton-Provencher et al., 2009; Lazarini et al., 2009; Sultan et al., 2010). Therefore, CTR and $2 \times$ Tg mice were retested $28 \mathrm{~d}$ after the completion of training. In this remote test, both CTR $\left(t_{(9)}=\right.$ $6.61, p<0.0001)$ and $2 \times \operatorname{Tg}\left(t_{(10)}=3.28, p<0.01\right)$ mice continued to express a preference for the reinforced odor (Fig. $5 b, c$ ), indicating that pretraining ablation of OGCs did not alter the persistence of an odor-reward memory. The lack of effect of pretraining ablation on the formation and persistence of odorreward memories was supported by comparisons of preference 
a

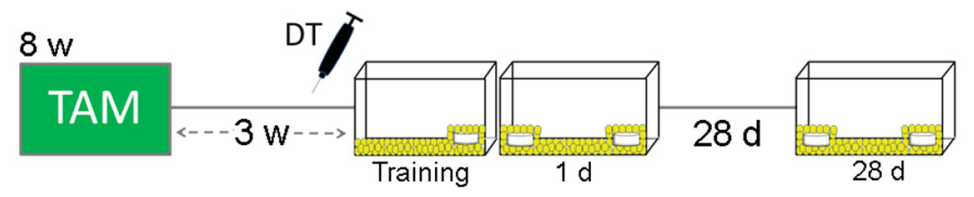

b

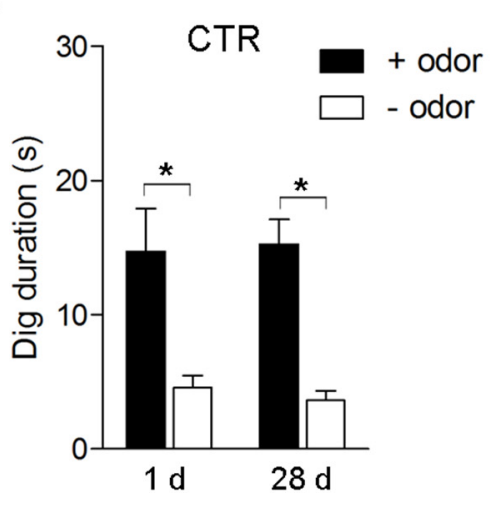

C

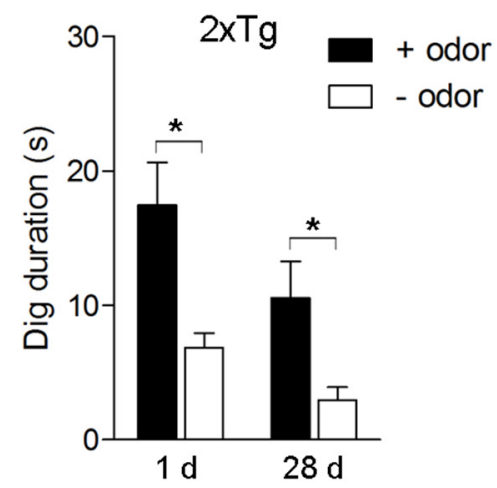

d

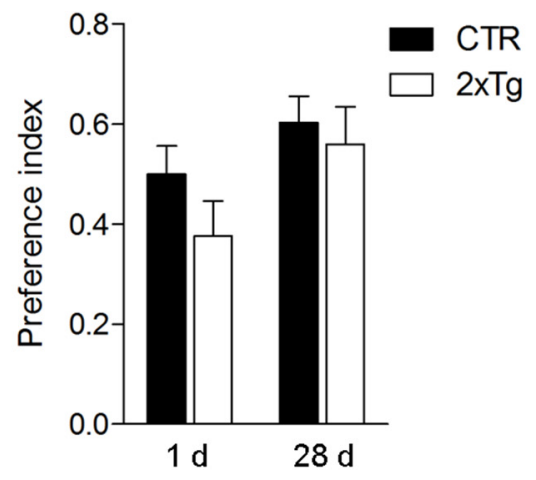

Figure 5. Pretraining ablation of adult-generated $0 \mathrm{GCs}$ does not prevent acquisition of an odor-reward memory. $\boldsymbol{a}$, Adult mice were treated with TAM and trained in the odor-reward task 3 weeks later. Mice were treated daily with DT for $5 \mathrm{~d}$ immediately preceding training. Odor-reward memory was evaluated 1 and $28 \mathrm{~d}$ after the completion of training. Both (TR ( $\boldsymbol{b})$ and $2 \times \operatorname{Tg}(\boldsymbol{c})$ mice spent more time digging over the previously reinforced odor in probe tests 1 and $28 \mathrm{~d}$ after training. $\boldsymbol{d}$, Preference indices for CTR and $2 \times \operatorname{Tg}$ mice in the 1 and $28 \mathrm{~d}$ tests. ${ }^{*} p<0.05$.
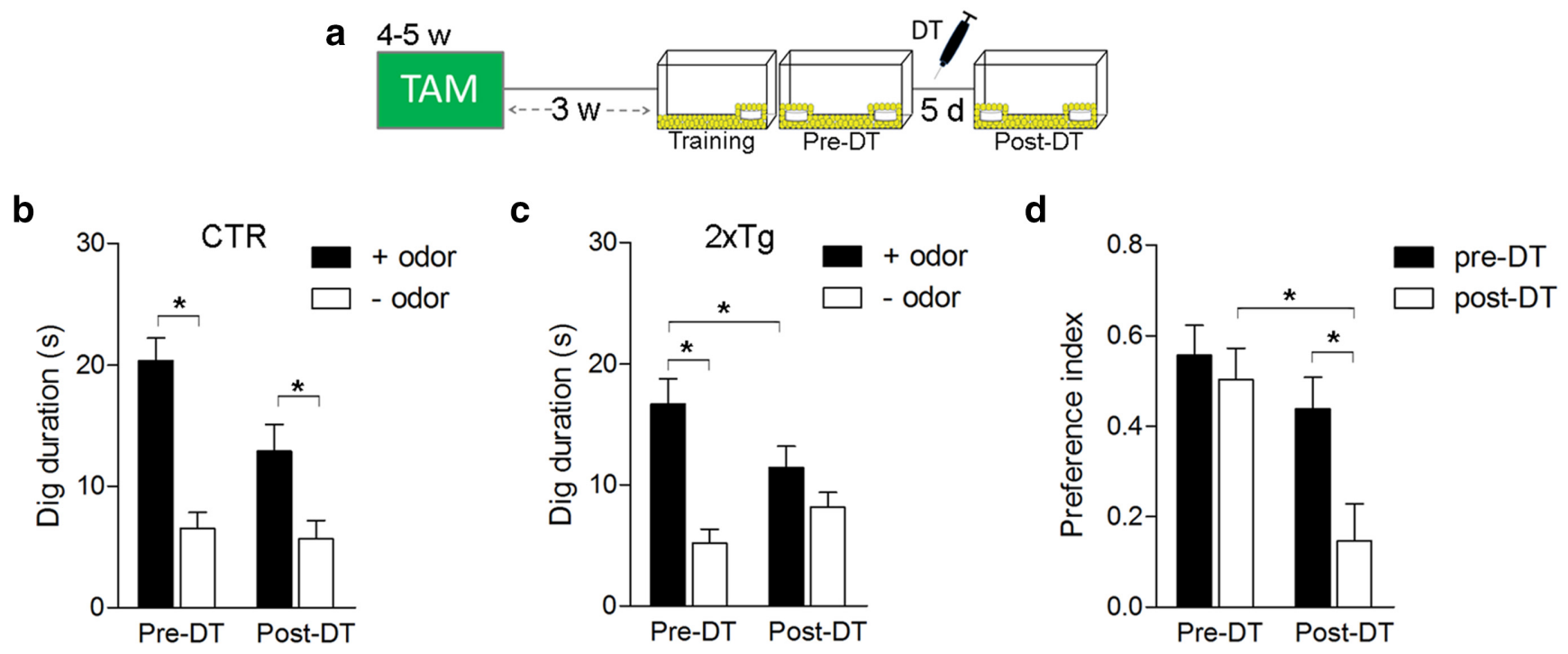

Figure 6. Posttraining ablation of juvenile-generated OGCs impairs odor-reward memory. $\boldsymbol{a}$, Juvenile (4-5 weeks old) mice were treated with TAM and trained in the odor-reward task 3 weeks later. 0dor-reward memory was evaluated $1 \mathrm{~d}$ after training (pre-DT probe) and again after DT treatment (post-DT probe). $\boldsymbol{b}$, (TR mice spent more time digging over the previously reinforced odor in the probe tests before and after DT treatment. c, Although $2 \times \operatorname{Tg}$ mice spent more time digging over the previously reinforced odor in the pre-DT probe test, they spent equivalent time digging over the reinforced versus non-reinforced odors in the post-DT test. $\boldsymbol{d}$, Preference indices for CTR and $2 \times \operatorname{Tg}_{\text {mice in }}$ the pre-DT and post-DT tests. ${ }^{*} p<0.05$.

indices. An ANOVA with genotype and test time as factors revealed no main effects or genotype $\times$ test time interactions (Fig. $5 d)$. Therefore, whereas ablating adult-generated OGCs after training leads to memory loss, ablating an equivalent population of cells before training does not prevent the formation of an odor-reward memory. This suggests that existing OGCs may support the formation of odor-reward memory.

\section{Posttraining ablation of juvenile-generated OGCs impairs} expression of an odor-reward memory

We next tested whether a similar dissociation between the effects of pretraining versus posttraining ablation of OGCs would be observed in younger, 4 - to 5-week-old mice (an age that corresponds to juvenility; Wei et al., 2011). Using an protocol identical to that used for adult mice, we first assessed the effect of posttraining ablation of OGCs generated during juvenility (Fig. 6a). Similar to adult mice, we found that posttraining ablation led to memory loss. Whereas CTR mice expressed a preference for the reinforced odor both before $\left(t_{(17)}=6.80, p<0.0001\right)$ and after $\left(t_{(17)}=5.80, p<0.0001\right)$ DT treatment (Fig. $\left.6 b\right), 2 \times$ Tg mice only expressed a preference for the reinforced odor before DT treatment $\left(t_{(18)}=4.77, p<0.0005\right)$. After DT treatment, $2 \times \mathrm{Tg}$ mice investigated the reinforced and non-reinforced odors equivalently $\left(t_{(18)}=1.70, p=0.11\right.$; Fig. $\left.6 c\right)$.

This pattern of results was confirmed by comparisons of preference indices. An ANOVA with genotype (CTR, $2 \times \mathrm{Tg}$ ) as a between-subjects variable and test time (pre-DT, post-DT) as a within-subjects variable revealed main effects of genotype 
$\left(F_{(1,35)}=6.44, p<0.05\right)$ and test time $\left(F_{(1,35)}=12.11, p<0.005\right)$. However, the ANOVA indicated that the genotype $X$ test time interaction only approached significance $\left(F_{(1,35)}=3.02, p=0.09\right)$, and so these results should be interpreted with more caution. Nonetheless, planned comparisons indicated that, whereas preference for the reinforced odor was similar before and after DT treatment for CTR mice $\left(t_{(17)}=1.13, p=0.28\right)$, it was significantly reduced after DT treatment in $2 \times \operatorname{Tg}$ mice $\left(t_{(18)}=4.19, p<0.001\right.$; Fig. $6 d)$. Furthermore, during the post-DT test, preference for the reinforced odor was significantly reduced in $2 \times \mathrm{Tg}$ compared with CTR mice $\left(t_{(35)}=2.70, p=\right.$ 0.011). Importantly, these contrasts remain significant even after correcting for multiple comparisons.

We next assessed the effect of pretraining ablation of OGCs generated during juvenility. Again, using a protocol identical to that used for adult mice (Fig. 7a), we found that pretraining ablation did not prevent the formation of a persistent odor-reward memory. Both CTR and $2 \times \mathrm{Tg}$ mice expressed preference for the reinforced odor when tested $1 \mathrm{~d}$ (CTR, $t_{(14)}=5.33, p<0.0001 ; 2 \times \mathrm{Tg}, t_{(14)}=$ $5.14, p<0.0001)$ or $28 \mathrm{~d}\left(\mathrm{CTR}, t_{(14)}=\right.$ $3.76, p<0.005 ; 2 \times \mathrm{Tg}, t_{(14)}=2.71, p<$ 0.05 ) after training (Fig. $7 b, c$ ). Moreover, the degree of preference did not change with time or genotype (genotype $\times$ test time ANOVA, no main effects or interactions; Fig. 7d). Similar to adult mice, these results suggest that existing OGCs may compensate for the pretraining loss of juvenile-generated OGCs.

\section{Adult-generated OGCs are only transiently necessary for expression of an odor-reward memory}

Odor-reward memories may persist for many weeks. For example, using training conditions similar to those used here, mice were able to express an odor preference up to $28 \mathrm{~d}$ after training (Schellinck et al., 2001). Therefore, we next asked whether adultgenerated OGCs are always necessary for expression of an odorreward memory once learned or whether memory expression becomes independent of this population of cells over time. To do this, adult CTR and $2 \times \mathrm{Tg}$ mice were treated with TAM and trained 3 weeks later, and memory was tested $1 \mathrm{~d}$ after training (pre-DT probe). Mice were then treated with DT 4 weeks later (rather than immediately) and memory was reassessed (post-DT probe; Fig. 8a). We found that ablating adult-generated OGCs 1 month after learning did not affect subsequent expression of that memory. Both CTR and $2 \times$ Tg mice expressed a preference for the reinforced odor in pre-DT $\left(\mathrm{CTR}, t_{(15)}=6.22, p<0.0001\right.$; $\left.2 \times \mathrm{Tg}, t_{(7)}=6.36, p<0.0005\right)$ and post-DT $\left(\mathrm{CTR}, t_{(15)}=3.52\right.$, $\left.p<0.005 ; 2 \times \mathrm{Tg}, t_{(7)}=3.28, p<0.05\right)$ tests, and the magnitude of this preference was similar at both time points for both CTR and $2 \times$ Tg mice (genotype $\times$ test time ANOVA, no main effects or interactions, all $F$ values $<1$; Fig. $8 b-d$ ). These results contrast

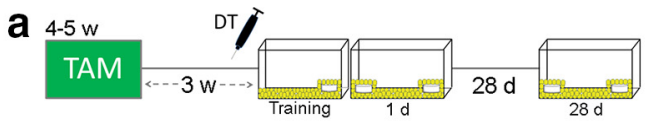

d

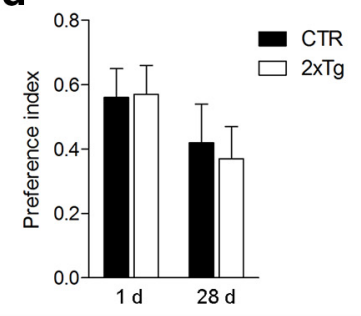

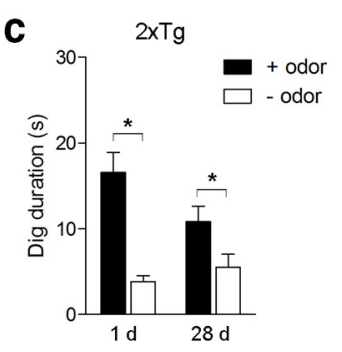

C

Figure 7. Pretraining ablation of juvenile-generated OGCs does not prevent acquisition of an odor-reward memory. $\boldsymbol{a}$, Juvenile

b

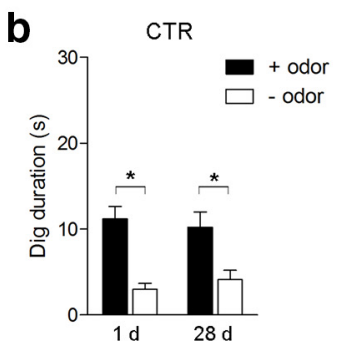
(n) 
In previous ablation studies, neural stem and/or progenitor cells were targeted and therefore behavior was studied after a global reduction in adult neurogenesis (Imayoshi et al., 2008; Breton-Provencher et al., 2009; Lazarini et al., 2009; Moreno et al., 2009; Valley et al., 2009; Feierstein et al., 2010; Sultan et al., 2010; Sakamoto et al., 2011; Cushman et al., 2012; Feierstein, 2012). The present DTR-based ablation approach differs in so far as we were able to study the effect of depletion of large numbers of adult-generated OGCs that were already mature and, presumably, synaptically integrated into OB circuits at the time of training. In particular, this tag-and-ablate approach allowed us control over the timing of the target and ablation of cells after (as well as before) training. This latter feature is important because it allowed us to ablate adult-generated OGCs that have had the opportunity to become integrated into odor memory circuits. Consistent with the idea that targeting "memory-committed" cells would be more powerful (Frankland, 2013), we found that posttraining (but not pretraining) ablations impaired memory.

Our finding that posttraining ablations impaired memory suggests that, if available at the time of training, adult-generated OGCs are essential for expression of an odor-reward memory. These loss-of-function data complement a recent gain-offunction study that showed that optical stimulation of adultgenerated OGCs facilitated the formation of odor-reward memories (Alonso et al., 2012). In our study, memory loss was most likely associated with ablation of cells that were $>10 \mathrm{~d}$ of age, because similar posttraining ablations of cells that were $\leq 10$ $\mathrm{d}$ of age at the time of training did not lead to memory loss. This corresponds to a time point when OGCs have synaptically integrated into $\mathrm{OB}$ circuits and display heightened plasticity at input synapses (Nissant et al., 2009) and responsivity to novel odors and olfactory learning (Magavi et al., 2005; Sultan et al., 2010; Belnoue et al., 2011; Lepousez et al., 2014). Furthermore, the developmental stage at which OGCs were generated did not appear to matter. Both posttraining ablation of OGCs generated during juvenility or adulthood led to memory loss. Previous studies suggest that OGCs generated during earlier developmental stages/juvenility may make distinct contributions to olfactorymediated social affiliative behaviors (Wei et al., 2011). The current results suggest that these findings do not generalize to odor-reward memories. Finally, although we used a Cre-driver line with highest recombination efficiency in the SVZ (line 5-1 from the study of Imayoshi et al., 2008), DT-induced ablation should also effect significant numbers of adult-generated dentate granule cells in the hippocampus. However, it is unlikely that the memory deficits we observed were attributable to a loss of dentate granule cells, because lesions of the entire hippocampus do not affect this type of odor-reward memory (Akers et al., 2011).

DT injections efficiently ablate DTR-tagged cells. Based on our fate-mapping analyses, we estimate that our DT injections led to the loss of large numbers of adult-generated OGCs $(>140,000$ cells). Although DT-induced ablations are associated with minimal inflammation (Buch et al., 2005; Han et al., 2009; Arruda-Carvalho et al., 2011), it is possible that widespread apoptotic cell death might generally disrupt $\mathrm{OB}$ function. However, neither posttraining ablation of predominantly immature cells $(<10$-d-old cells) nor ablation of a similar population of OGCs before training disrupted odorreward memory. This suggests that the DT-induced ablation did not generally impair odor perception or alter motivation and motor skills required for learning the odor-reward association.

Control over the timing of the ablation made it possible to additionally explore the role of adult-generated OGCs in the continued expression of odor-reward memories, long after initial training. Whereas ablation of adult-generated OGCs soon after training led to a loss of odor-reward memory, similar ablations 4 weeks after training were ineffective. Odor-reward memories are likely supported by a distributed circuit including populations of cells that are both intrinsic and extrinsic to the OB. Our results suggest that these circuits are dynamic and change over time, with OGCs playing only a transient role in the expression of odorreward memories. Consistent with this evidence for timedependent reorganization of circuits supporting odor-reward memories, a recent immediate early gene mapping study suggests that $\sim 5$-week-old adult-generated OGCs are engaged during odor learning but are no longer activated when that memory is recalled 4 weeks later (Belnoue et al., 2011). This time-dependent role for adult-generated OGCs in odor-reward memories mirrors the role of the hippocampus in episodic-like memories (Frankland and Bontempi, 2005). For example, expression of contextual fear memories are initially dependent on the hippocampus, but after $\sim 1$ month, these types of memories may be expressed independently of the hippocampus (Kim and Fanselow, 1992). An interesting parallel between the OB and the hippocampus is that, in both systems, there is continuous integration of new neurons into existing circuits. In the hippocampus, this continuous neurogenesis-associated remodeling may degrade information already stored in these circuits (Feng et al., 2001; Meltzer et al., 2005; Kitamura et al., 2009; Josselyn and Frankland, 2012; Frankland et al., 2013; Akers et al., 2014). This degradation of the hippocampal trace, coupled with the strengthening of corticocortical connections, is thought to underlie the transformation of the memory from a hippocampus-dependent to hippocampus-independent form (Frankland and Bontempi, 2005). Similarly, it is possible that continuous integration of adult-generated OGCs degrades information stored within the $\mathrm{OB}$ such that, with time, expression of olfactory memories no longer critically depends on OGCs but may be supported by cortical networks alone. One caveat is worth noting here. An alternative possibility is that conditionally expressed DTRs are degraded during this period, rendering "tagged" cells no longer sensitive to DT at more remote time points. Although this is possible, our previous studies using this system in the hippocampus suggest that this is unlikely (Arruda-Carvalho et al., 2011). In these studies, DT-induced ablations induced amnesia, even when initiated several weeks after TAM-induced DTR expression.

What role might adult-generated OGCs play in the expression of odor-reward memories? There are at least two possibilities. First, adult-generated OGCs might represent informationstoring units themselves in a broader circuit, likely including higher-order cortical regions such as the piriform cortex, anterior olfactory nucleus, and cortical amygdaloid nucleus, and loss of this population of cells soon after training degrades the representation of the odor-reward association sufficiently that mice are no longer able to discriminate between similar reinforced and non-reinforced odors. An alternate possibility is that, rather than storing information, adult-generated OGCs might modulate the efficiency of retrieval of information stored elsewhere (e.g., in other OB cells). For example, adult-generated OGCs regulate synchronous firing of mitral cells via dendrodendritic synapses (Urban and Arevian, 2009), and disrupted synchrony may impair retrieval and/or discrimination between similar odors. These two possibilities are difficult to disentangle. However, our finding that ablation of adult-generated OGCs only produced memory loss under a limited set of conditions favors an informationstorage account. In particular, the absence of memory loss after 
pretraining ablation of OGCs suggests that this type of ablation does not lead to a generalized dysregulation of retrieval.

\section{References}

Akers KG, Kushner SA, Leslie AT, Clarke L, van der Kooy D, Lerch JP, Frankland PW (2011) Fetal alcohol exposure leads to abnormal olfactory bulb development and impaired odor discrimination in adult mice. Mol Brain 4:29. CrossRef Medline

Akers KG, Martinez-Canabal A, Restivo L, Yiu AP, De Cristofaro A, Hsiang HL, Wheeler AL, Guskjolen A, Niibori Y, Shoji H, Ohira K, Richards BA, Miyakawa T, Josselyn SA, Frankland PW (2014) Hippocampal neurogenesis regulates forgetting during adulthood and infancy. Science 344: 598-602. CrossRef Medline

Alonso M, Lepousez G, Sebastien W, Bardy C, Gabellec MM, Torquet N, Lledo PM (2012) Activation of adult-born neurons facilitates learning and memory. Nat Neurosci 15:897-904. CrossRef Medline

Archer J (1973) Tests for emotionality in rats and mice: a review. Anim Behav 21:205-235. CrossRef Medline

Arruda-Carvalho M, Sakaguchi M, Akers KG, Josselyn SA, Frankland PW (2011) Posttraining ablation of adult-generated neurons degrades previously acquired memories. J Neurosci 31:15113-15127. CrossRef Medline

Belnoue L, Grosjean N, Abrous DN, Koehl M (2011) A critical time window for the recruitment of bulbar newborn neurons by olfactory discrimination learning. J Neurosci 31:1010-1016. CrossRef Medline

Belvindrah R, Lazarini F, Lledo PM (2009) Postnatal neurogenesis: from neuroblast migration to neuronal integration. Rev Neurosci 20:331-346. Medline

Breton-Provencher V, Lemasson M, Peralta MR 3rd, Saghatelyan A (2009) Interneurons produced in adulthood are required for the normal functioning of the olfactory bulb network and for the execution of selected olfactory behaviors. J Neurosci 29:15245-15257. CrossRef Medline

Buch T, Heppner FL, Tertilt C, Heinen TJ, Kremer M, Wunderlich FT, Jung S, Waisman A (2005) A Cre-inducible diphtheria toxin receptor mediates cell lineage ablation after toxin administration. Nat Methods 2:419-426. CrossRef Medline

Carleton A, Petreanu LT, Lansford R, Alvarez-Buylla A, Lledo PM (2003) Becoming a new neuron in the adult olfactory bulb. Nat Neurosci 6:507518. CrossRef Medline

Chen GH, Wang YJ, Zhang LQ, Zhou JN (2004) Age- and sex-related disturbance in a battery of sensorimotor and cognitive tasks in Kunming mice. Physiol Behav 83:531-541. CrossRef Medline

Cleland TA (2010) Early transformations in odor representation. Trends Neurosci 33:130-139. CrossRef Medline

Cushman JD, Maldonado J, Kwon EE, Garcia AD, Fan G, Imura T, Sofroniew MV, Fanselow MS (2012) Juvenile neurogenesis makes essential contributions to adult brain structure and plays a sex-dependent role in fear memories. Front Behav Neurosci 6:3. CrossRef Medline

Feierstein CE (2012) Linking adult olfactory neurogenesis to social behavior. Front Neurosci 6:173. CrossRef Medline

Feierstein CE, Lazarini F, Wagner S, Gabellec MM, de Chaumont F, OlivoMarin JC, Boussin FD, Lledo PM, Gheusi G (2010) Disruption of adult neurogenesis in the olfactory bulb affects social interaction but not maternal behavior. Front Behav Neurosci 4:176. CrossRef Medline

Feng R, Rampon C, Tang YP, Shrom D, Jin J, Kyin M, Sopher B, Miller MW, Ware CB, Martin GM, Kim SH, Langdon RB, Sisodia SS, Tsien JZ (2001) Deficient neurogenesis in forebrain-specific presenilin-1 knockout mice is associated with reduced clearance of hippocampal memory traces. Neuron 32:911-926. CrossRef Medline

Forni PE, Scuoppo C, Imayoshi I, Taulli R, Dastrù W, Sala V, Betz UA, Muzzi P, Martinuzzi D, Vercelli AE, Kageyama R, Ponzetto C (2006) High levels of Cre expression in neuronal progenitors cause defects in brain development leading to microencephaly and hydrocephaly. J Neurosci 26 : 9593-9602. CrossRef Medline

Frankland PW (2013) Neurogenic evangelism: comment on Urbach et al. (2013). Behav Neurosci 127:126-129. CrossRef Medline

Frankland PW, Bontempi B (2005) The organization of recent and remote memories. Nat Rev Neurosci 6:119-130. CrossRef Medline

Frankland PW, Köhler S, Josselyn SA (2013) Hippocampal neurogenesis and forgetting. Trends Neurosci 36:497-503. CrossRef Medline

Gao Y, Strowbridge BW (2009) Long-term plasticity of excitatory inputs to granule cells in the rat olfactory bulb. Nat Neurosci 12:731-733. CrossRef Medline

Gropp E, Shanabrough M, Borok E, Xu AW, Janoschek R, Buch T, Plum L, Balthasar N, Hampel B, Waisman A, Barsh GS, Horvath TL, Brüning JC (2005) Agouti-related peptide-expressing neurons are mandatory for feeding. Nat Neurosci 8:1289-1291. CrossRef Medline

Gundersen HJ, Jensen EB, Kiêu K, Nielsen J (1999) The efficiency of systematic sampling in stereology—reconsidered. J Microsc 193:199-211. CrossRef Medline

Han JH, Kushner SA, Yiu AP, Hsiang HL, Buch T, Waisman A, Bontempi B, Neve RL, Frankland PW, Josselyn SA (2009) Selective erasure of a fear memory. Science 323:1492-1496. CrossRef Medline

Imayoshi I, Sakamoto M, Ohtsuka T, Takao K, Miyakawa T, Yamaguchi M, Mori K, Ikeda T, Itohara S, Kageyama R (2008) Roles of continuous neurogenesis in the structural and functional integrity of the adult forebrain. Nat Neurosci 11:1153-1161. CrossRef Medline

Josselyn SA, Frankland PW (2012) Infantile amnesia: a neurogenic hypothesis. Learn Mem 19:423-433. CrossRef Medline

Kim JJ, Fanselow MS (1992) Modality-specific retrograde amnesia of fear. Science 256:675-677. CrossRef Medline

Kitamura T, Saitoh Y, Takashima N, Murayama A, Niibori Y, Ageta H, Sekiguchi M, Sugiyama H, Inokuchi K (2009) Adult neurogenesis modulates the hippocampus-dependent period of associative fear memory. Cell 139:814-827. CrossRef Medline

Lagace DC, Whitman MC, Noonan MA, Ables JL, DeCarolis NA, Arguello AA, Donovan MH, Fischer SJ, Farnbauch LA, Beech RD, DiLeone RJ, Greer CA, Mandyam CD, Eisch AJ (2007) Dynamic contribution of nestin-expressing stem cells to adult neurogenesis. J Neurosci 27:1262312629. CrossRef Medline

Lazarini F, Lledo PM (2011) Is adult neurogenesis essential for olfaction? Trends Neurosci 34:20-30. CrossRef Medline

Lazarini F, Mouthon MA, Gheusi G, de Chaumont F, Olivo-Marin JC, Lamarque S, Abrous DN, Boussin FD, Lledo PM (2009) Cellular and behavioral effects of cranial irradiation of the subventricular zone in adult mice. PLoS One 4:e7017. CrossRef Medline

Lepousez G, Valley MT, Lledo PM (2013) The impact of adult neurogenesis on olfactory bulb circuits and computations. Annu Rev Physiol 75:339 363. CrossRef Medline

Lepousez G, Nissant A, Bryant AK, Gheusi G, Greer CA, Lledo PM (2014) Olfactory learning promotes input-specific synaptic plasticity in adult-born neurons. Proc Natl Acad Sci U S A 111:13984-13989. CrossRef Medline

Magavi SS, Mitchell BD, Szentirmai O, Carter BS, Macklis JD (2005) Adultborn and preexisting olfactory granule neurons undergo distinct experience-dependent modifications of their olfactory responses in vivo. J Neurosci 25:10729-10739. CrossRef Medline

Meltzer LA, Yabaluri R, Deisseroth K (2005) A role for circuit homeostasis in adult neurogenesis. Trends Neurosci 28:653-660. CrossRef Medline

Ming GL, Song H (2005) Adult neurogenesis in the mammalian central nervous system. Annu Rev Neurosci 28:223-250. CrossRef Medline

Moreno MM, Linster C, Escanilla O, Sacquet J, Didier A, Mandairon N (2009) Olfactory perceptual learning requires adult neurogenesis. Proc Natl Acad Sci U S A 106:17980-17985. CrossRef Medline

Mouret A, Murray K, Lledo PM (2009) Centrifugal drive onto local inhibitory interneurons of the olfactory bulb. Ann N Y Acad Sci 1170:239-254. CrossRef Medline

Nissant A, Bardy C, Katagiri H, Murray K, Lledo PM (2009) Adult neurogenesis promotes synaptic plasticity in the olfactory bulb. Nat Neurosci 12:728-730. CrossRef Medline

Saito M, Iwawaki T, Taya C, Yonekawa H, Noda M, Inui Y, Mekada E, Kimata Y, Tsuru A, Kohno K (2001) Diphtheria toxin receptor-mediated conditional and targeted cell ablation in transgenic mice. Nat Biotechnol 19:746-750. CrossRef Medline

Sakamoto M, Imayoshi I, Ohtsuka T, Yamaguchi M, Mori K, Kageyama R (2011) Continuous neurogenesis in the adult forebrain is required for innate olfactory responses. Proc Natl Acad Sci U S A 108:8479-8484. CrossRef Medline

Schellinck HM, Forestell CA, LoLordo VM (2001) A simple and reliable test of olfactory learning and memory in mice. Chem Senses 26:663-672. CrossRef Medline

Sultan S, Mandairon N, Kermen F, Garcia S, Sacquet J, Didier A (2010) Learning-dependent neurogenesis in the olfactory bulb determines longterm olfactory memory. FASEB J 24:2355-2363. CrossRef Medline 
Urban NN, Arevian AC (2009) Computing with dendrodendritic synapses in the olfactory bulb. Ann N Y Acad Sci 1170:264-269. CrossRef Medline

Valley MT, Mullen TR, Schultz LC, Sagdullaev BT, Firestein S (2009) Ablation of mouse adult neurogenesis alters olfactory bulb structure and olfactory fear conditioning. Front Neurosci 3:51. CrossRef Medline

Vukovic J, Borlikova GG, Ruitenberg MJ, Robinson GJ, Sullivan RK, Walker TL, Bartlett PF (2013) Immature doublecortin-positive hippocampal neurons are important for learning but not for remembering. J Neurosci 33:6603-6613. CrossRef Medline

Wei L, Meaney MJ, Duman RS, Kaffman A (2011) Affiliative behavior requires juvenile, but not adult neurogenesis. J Neurosci 31:14335-14345. CrossRef Medline

Whiddon BB, Palmiter RD (2013) Ablation of neurons expressing melanin- concentrating hormone $(\mathrm{MCH})$ in adult mice improves glucose tolerance independent of MCH signaling. J Neurosci 33:2009-2016. CrossRef Medline

Winner B, Cooper-Kuhn CM, Aigner R, Winkler J, Kuhn HG (2002) Longterm survival and cell death of newly generated neurons in the adult rat olfactory bulb. Eur J Neurosci 16:1681-1689. CrossRef Medline

Wrobel CJ, Wright DC, Dedrick RL, Youle RJ (1990) Diphtheria toxin effects on brain-tumor xenografts. Implications for protein-based braintumor chemotherapy. J Neurosurg 72:946-950. CrossRef Medline

Zambrowicz BP, Imamoto A, Fiering S, Herzenberg LA, Kerr WG, Soriano P (1997) Disruption of overlapping transcripts in the ROSA beta geo 26 gene trap strain leads to widespread expression of beta-galactosidase in mouse embryos and hematopoietic cells. Proc Natl Acad Sci U S A 94: 3789-3794. CrossRef Medline 